\title{
ENSINO E PESQUISA ACERCA DA LEITURA E DA LITERATURA INFANTIL E JUVENIL: REFLEXÕES COM RENATA JUNQUEIRA
}

\begin{abstract}
Renata Junqueira de Souza
Doutora em Letras pela Universidade Estadual Paulista Júlio de Mesquita Filho (UNESP) Professora Assistente Doutora da Universidade Estadual Paulista Júlio de Mesquita Filho

(UNESP) / Campus Presidente Prudente
\end{abstract}

Entrevistada por:

Everaldo Lima de Araújo

Doutorando em Letras - Língua Portuguesa - pela Universidade do Estado do Rio de Janeiro (UERJ) ever.lima.araujo@gmail.com

Márcia da Gama Silva Felipe

Doutoranda em Letras - Língua Portuguesa - pela Universidade do Estado do Rio de Janeiro (UERJ) prof.marciadagama@gmail.com

Thales Sant'Ana Ferreira Mendes

Mestrando em Letras - Literatura Brasileira - pela Universidade do Estado do Rio de Janeiro (UERJ) thales.sanfer@hotmail.com

Renata Junqueira possui graduação em Letras pela Universidade Estadual Paulista Júlio de Mesquita Filho (UNESP) (1987), mestrado em Linguística e Letras pela Pontifícia Universidade Católica do Rio Grande do Sul (PUC-RS) (1990), doutorado em Letras pela Universidade Estadual Paulista Júlio de Mesquita Filho (UNESP) (2000) e é livre-docente pela mesma instituição (2012) no conjunto das disciplinas Conteúdos, Metodologia e Prática de Ensino de Língua Portuguesa I e II e Leitura, Literatura e Interpretação de Textos no Processo de Formação de Professores. Atualmente é professora visitante da Universidade do Minho (Portugal) e professora assistente doutor da Universidade Estadual Paulista Júlio de Mesquita Filho (UNESP). Tem experiência na área de Educação, com ênfase em Ensino-Aprendizagem, atuando principalmente nos seguintes temas: leitura, formação de leitores, literatura infantil, literatura e formação de professores, estratégias de leitura.

Pesquisadora experiente na temática da leitura e da literatura infantil e juvenil, com profícua e sólida pesquisa, possui também vasta interlocução sobre os temas, no Brasil e no exterior. Gentilmente, com o intuito de compartilhar conosco um pouco de suas vivências, reflexões e paixões pela literatura e pelo ensino, a professora Renata Junqueira nos concedeu esta entrevista, via e-mail, com a mesma presteza e disposição que marcam sua trajetória acadêmica. 


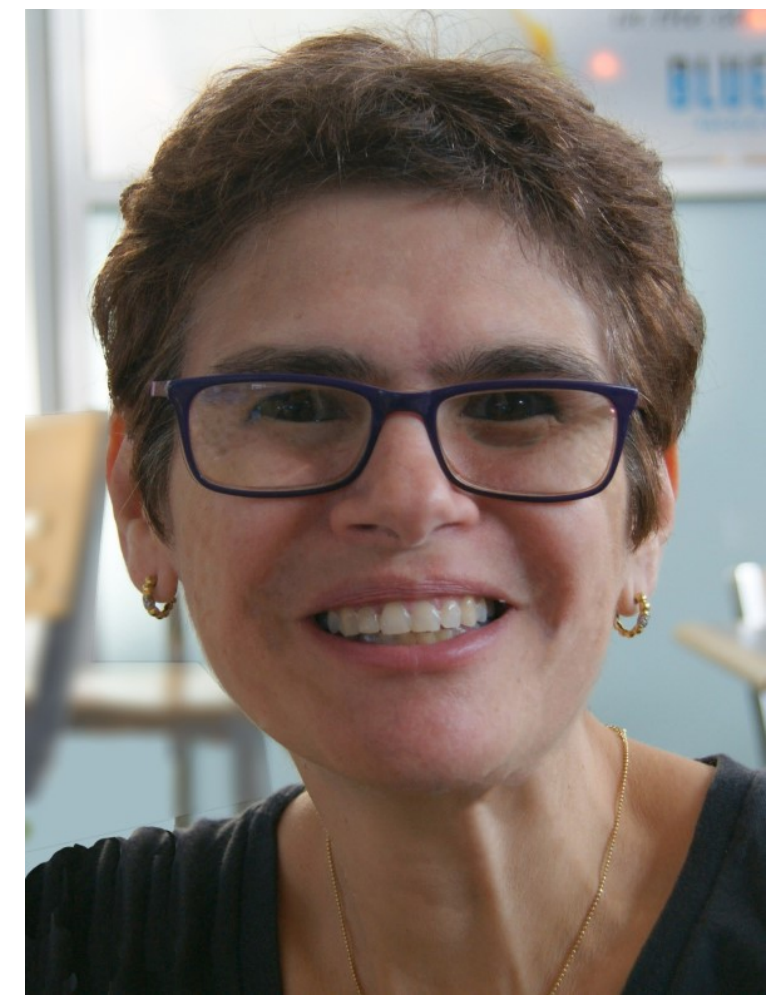

\section{PALIMPSESTO}

1) Houve um tempo em que a literatura infantil era considerada um gênero menor dentro do âmbito literário. A senhora acha que essa visão ainda persiste hoje em dia?

\section{RENATA JUNQUEIRA}

Infelizmente tenho que dizer que sim, muitos docentes ainda não atribuíram à literatura infantil seu verdadeiro valor. E digo isso entristecida, pois, ao descobrir as possibilidades de interação entre texto literário e estratégias de leitura, poderíamos motivar crianças e jovens a entrar nas páginas dos livros.

\section{PALIMPSESTO}


2) Levando em conta a atual sociedade altamente influenciada pelas tecnologias e os avanços advindos da internet, qual o lugar da literatura para crianças e jovens, sobretudo numa perspectiva que favoreça a formação de leitores?

\section{RENATA JUNQUEIRA}

Sempre defendi a diversidade, isto é, diversidade de gêneros e tipos textuais, muitos temas diferentes com probabilidades de ricas discussões em sala de aula, diversas materialidades, incluindo o texto digital. Assim, também seria interessante pensarmos nos mediadores de leitura, pois são eles que irão formar o pequeno e jovem leitor. Pensemos em pais, professores, bibliotecários e porque não incluir o espaço formador. Tais sujeitos mediadores devem inicialmente ofertar essa diversidade para motivar os gestos, os atos de leitura. Acredito que, com essa exposição, a criança/jovem se interessará pelo livro, seja ele em qualquer ou todas materialidades. Fomentar e sedimentar esse leitor em formação, dependerá a seguir, do trabalho de mediação.

\section{PALIMPSESTO}

3) Muitas escolas adotam livros paradidáticos cuja leitura é obrigatória. Como lidar, nesse caso, com o incentivo à leitura, considerando as avaliações demandadas por essas escolas?

\section{RENATA JUNQUEIRA}


As escolas muitas vezes confundem o literário, paradidático e didático. Para mim, o paradidático é aquele que distrai educando, ou seja, a obra não é aberta e o leitor acaba não tendo liberdade na atribuição de sentidos à obra, as compreensões serão iguais, pois há sempre uma ficção que "maqueia" valores e lições a serem aprendidas. Enquanto gestores, coordenadores pedagógicos e professores não tiverem essa formação, a literatura acaba não entrando em sala de aula, ou entra de modo inadequado, pois percebo que a escola quer sempre dar uma utilidade ao texto literário, desvirtuando de sua verdadeira função, a de humanizar o leitor.

\section{PALIMPSESTO}

4) Que impacto(s) poderia(m) ter a literatura para crianças e jovens no tocante ao desenvolvimento intelectual desses leitores?

\section{RENATA JUNQUEIRA}

Tenho há 6 anos pesquisado sobre literatura para bebês e posso dizer que a oferta e mediação são importantes para desenvolver a fala, a afetividade, atividades de faz-deconta e jogos de papeis tão importantes para o desenvolvimento intelectual, motor e afetivo desses pequenos, sem contar a criatividade, a imaginação e a memória. Todas essas habilidades podem ser instigadas a partir dos livros. Penso ainda que será a partir das vivências pessoais, das leituras oportunizadas na infância que o conhecimento prévio dos sujeitos será construído e ampliado e, para compreender o mundo e os textos, é muito importante termos conhecimento, repertório, caso contrário, não teremos sujeitos críticos, que devem compreender a si mesmos e ao mundo. 


\section{PALIMPSESTO}

5) No contexto atual das pesquisas brasileiras, como a senhora avalia a produção de estudos sobre a literatura infantil e juvenil?

\section{RENATA JUNQUEIRA}

Cada vez maior. E chega a ser um contra senso se pensarmos que ainda há preconceitos com relação a esse tipo de produção intelectual. Os mestrados profissionais, por exemplo, foi um ganho para os professores que podem muitas vezes pesquisar sua própria prática ou de colegas, mas acima de tudo fazer o diálogo entre teoria e práticas educativas. Os grupos de pesquisas, grupos de trabalhos em eventos importantes também têm cada vez mais ampliado simpósios sobre literatura infantil e juvenil. Dossiês de revistas acadêmicas com grande circulação estão elegendo temas como letramento literário, temas sensíveis/polêmicos na literatura para infância, recepção de obras infantis, literatura infantil digital, entre tantos outros. Embora o mercado livreiro esteja passando por uma crise, aos poucos aqueles que acreditam na formação literária têm conseguido espalhar as benesses de ler, ouvir e contar um texto literário.

\section{PALIMPSESTO}

6) Que caminhos têm sido atualmente trilhados pelos estudos da literatura infantojuvenil, tanto na perspectiva dos estudos literários, quanto na dos estudos da linguagem? 


\section{RENATA JUNQUEIRA}

Tenho visto uma forte tendência na didática do ensino da literatura infantil e juvenil. Recentemente estive na Universidade de Cuenca e há um grupo muito focado em discutir o ensino da literatura infantil em todos os seguimentos escolares. Também vindo de Portugal, estudos em que os pais dos alunos são formados como mediadores de leitura e isso é muito importante se pensarmos que o lar é o primeiro espaço em que a criança poderá ter contato com textos literários. As pesquisas sobre novos espaços de leitura, bebetecas, diferentes modos de ler também têm ganhado atenção na academia. $\mathrm{E}$ claro, na discussão sobre literatura contemporânea, estudos sobre projeto gráfico do livro, livros e mediação para a primeiríssima infância (bebês) e, por fim, estudos sobre a literatura digital e os temas sensíveis na ótica dos estudos culturais têm levado pesquisadores brasileiros ao exterior para dividir análises e avanços.

\section{PALIMPSESTO}

7) Que desafios a senhora indica para aqueles que procuram despertar em seus alunos o hábito da leitura?

\section{RENATA JUNQUEIRA}

Levar para sala de aula livros e ler. Ler de vários modos: leitura em capítulos, leitura compartilhada, clubes de leitura, leitura silenciosa, leitura da poesia. Atividades sobre autores, como o autor do mês, onde os livros de um determinado autor ficam em destaque no espaço da sala de aula e, no decorrer do mês, o professor faz um trabalho 
sobre o autor e/ou ilustrador, seu estilo, suas temáticas e os alunos compartilham seus achados, curiosidades, histórias e gostos. E por fim, que os professores conheçam as estratégias metacognitivas de leitura, pois elas também facilitarão essa mediação. E talvez o recado mais importante: que os professores tenham objetivos para as atividades de leitura, que deixem claro para os alunos quais objetivos são esses, pois podemos ler para informar, para divertir, para aprender, para emocionar, para lembrar e enquanto "futuro" leitor, o ato de ler tem que ter significado ao aluno. Só assim se forma o hábito. 


\title{
TEACHING AND RESEARCHING CHILDREN AND JUVENILE'S READING AND LITERATURE: REFLECTIONS BY RENATA JUNQUEIRA
}

\begin{abstract}
Translated into English by:
Jordana Lenhardt
\end{abstract}

PhD Student in Letters - Linguistics - by the State University of Rio de Janeiro (UERJ) jordana.uerj@gmail.com

Renata Junqueira is graduated in Letters by the State University of São Paulo Júlio de Mesquita Filho (UNESP) (1987), has a Master's Degree in Linguistics and Letters by the Pontifical Catholic University of the State of Rio Grande do Sul (PUC-RS) (1990), a Doctorate Degree in Letters the State University of São Paulo Júlio de Mesquita Filho (UNESP) (2000) and is a free teacher by the same university (2012) in subjects like Contents, Methodology and Portuguese Language Teaching Practices I and II and Reading, Literature and Text Comprehension in the Teaching Training Process. Currently, she is Visiting Professor in the Minho University (from Portugal) and Doctor Assistant Teacher in the State University of São Paulo Júlio de Mesquita Filho (UNESP). Professor Junqueira is experienced in the education area, with emphasis in teaching-learning, working mainly on issues like reading, readers training, children's literature, reading and teachers training, reading strategies.

Renata Junqueira is an experienced researcher in issues related to reading and children and juvenile's literature, she has developed profitable and solid researches and has interlocution in these themes in Brazil and abroad. Gently, the Professor has granted, by e-mail, this interview to share with us a little of her experiences, reflections and passion by literature and teaching, showing the same promptness and willingness that are remarkable in her academic trajectory. 


\section{PALIMPSESTO}

1) There was a time when children's literature was considered a minor gender in the literary field. Do you believe this kind of view still persists nowadays?

\section{RENATA JUNQUEIRA}

Unfortunately, I have to say yes, many teachers still haven't attributed to children's literature its real value. And I sadly say that, because realizing the interaction possibilities between literary texts and reading training could motivate children and young people to get in books pages.

\section{PALIMPSESTO}

2) Considering the current society is highly influenced by technology and some advances from the internet, what is the children and juvenile's literature place in there, regarding a perspective that favors the readers training?

\section{RENATA JUNQUEIRA}

I have always defended diversity, I mean, diversity of genders and textual types, many different themes with probabilities of rich discussions in classes, various materialities, including digital texts. Thereby, we should also consider reading mediators, because they are going to form small and young readers. We should think about parents, librarians and, why not, include the trainer space. These mediator subjects should initially offer diversity to motivate gesture and reading acts. I believe that with this exposing, 
Renata Junqueira, Everaldo L. de Araújo, Márcia da Gama S. Felipe e Thales Sant'Ana F. Mendes

children/young will become interested in books, being book in any or all of the materialities. Foment and sediment this reader in training then will be up to mediation work.

\section{PALIMPSESTO}

3) Many schools adopt literary textbooks which reading is required. How to deal, in this case, with reading incentive, considering evaluation exams demanded by these schools?

\section{RENATA JUNQUEIRA}

Schools may many times mistake literary, literary reading and didactic. For me, the literary reading is the one that entertains students, which means that if choosing the book is not an open choice to the reader, he/she ends up not having the book's sense assignment, because of that, comprehension is going to be the same, because there is also a fiction that "maps" values and lessons that should be learnt. While managers, coordinators and teachers do not have this training, literature is joint in classes or it takes part inappropriately. I see that schools usually want to give usefulness to literary texts, perverting its real function in humanizing the reader.

\section{PALIMPSESTO}

4) What impact(s) could children and juvenile's literature have in the intellectual development of readers? 


\section{RENATA JUNQUEIRA}

I have been researching baby's literature for 6 years and I can say that offering and mediating it is important for speaking and affectivity development, make-up activities and role play games are really important for the intellectual, motor and affectivity development of kids, besides creativity, imagination and memory. All these abilities can be instigated by books. I think that it's from experiences of readings in childhood that individual's previous knowledge will be constructed and extended, and to comprehend world and texts, it's really important to have knowledge and repertory, otherwise there won't be critical individuals, which can understand themselves and the world.

\section{PALIMPSESTO}

5) In the current Brazilian research context, how do you evaluate production of children and juvenile's studies?

\section{RENATA JUNQUEIRA}

It's been growing. And it can be some kind of paradox if we think about the prevailing prejudice with this kind of intellectual production. We can think about some Professional Master's Courses, for example, with which teachers can research their own practice or their classmates', but above it all, they can dialogue between educational theories and practice. Some research and work groups have also enlarged symposia about children and juvenile's literature. Some dossiers of academic journals with great circulation are electing themes like Literary literacy, some sensitive/polemic topics in 
Renata Junqueira, Everaldo L. de Araújo, Márcia da Gama S. Felipe e Thales Sant'Ana F. Mendes

literature for children, children books reception, digital children literature, among others. Thought the book Market is going through a crisis, slowly those who believe in the literary training are succeeding in spreading benefits of reading, hearing and telling literary text.

\section{PALIMPSESTO}

6) Which ways have been trodden by children and juvenile's literature studies, both in literary and language perspectives?

\section{RENATA JUNQUEIRA}

I see a strong trend in children and juvenile's literature didactics. Lately I've been to the Cuenca University, and there, there is a group focused in discussing children's literature teaching in all school segments. Also coming from Portugal, there are some studies in which students' parents are trained as reading mediators, and this is really important, thinking about home as the first space where kids can contact literary texts. The researches about new reading spaces, as baby libraries, also have gained some space in academy. And, of course, in the contemporary literature discussion, some studies about the books' graphic projects, books and mediation for the early childhood, and, finally, some studies about digital literature and some sensitive topics in the cultural studies scope have been taking Brazilian researchers abroad to share developments and analysis.

\section{PALIMPSESTO}


7) Which challenges do you indicate to those who want to arouse in their students the reading habits?

\section{RENATA JUNQUEIRA}

Taking books to class and reading them. Reading them in various ways: Reading in chapters, shared Reading, reading clubs, silent reading, poem reading. Activities about authors, like the month's author, in which the books of an author are prominently displayed in classroom within a month, the teacher demands some paperwork about the author and/or illustrator, his/her style and themes, students share what they found out, their curiosities, histories and likes. Lastly, that teachers know metacognitive reading strategies, because they will also facilitate this mediation. And maybe, the most important thing: that teachers have objectives for reading activities, that they make clear to students what these objectives are, because we can read to inform, to entertain, to learn, to thrill, to remember and as a "future" reader, the reading act must be meaningful to students. Only this way, habit is formed. 